\title{
RULERS OVER THE LAND THAT IS IOWA
}

\section{By ORA Williams}

Havana was the seat of authority for the last of the rulers over the land that is now Iowa.

There were rulers in those days ruling in the western world as well as elsewhere. During all of the eighteenth century the lands of the Mississippi valley were dominated by at least nominal rulers. About 140 years ago came the era of the governors who governed. The first rulers were French, and these were supplanted by Spanish. Of the latter at least two were distinctly Irish. Some of these rulers dangled long titles to their extended names. Many of them were men sent away to the wildderness for good riddance. Only a few had capacity either to rule or to govern.

At the close of the era of the rulers, the last of them seems to have been subordinate to a captain general on the isle of Cuba, who had general military direction of affairs for his country in North America. There was a governor general in New Orleans and a lieutenant in St. Louis, but since the colonial system of the time was bottomed on military power, all reports on the way to "his Catholic majesty" were channeled through Havana. The pompous officer there probably never heard of the Des Moines valley and he didn't care how many pelts were carried down the great river. Both for France and for Spain colonization was for the army and navy. Civil government, if and when needed, could come later. Not until the United States took over did the governors try to really govern by law.

The French rulers of Louisiana functioned from Montreal and the Spanish from New Orleans. At least during the latter part of the Spanish ownership, a deputy was stationed at St. Louis. The Spanish land grants along the Mississippi river came from the official in 
charge at St. Louis, and there was some question as to his right to make such favors. The following is the list of governors during the Eighteenth century:

French Provincial Governors

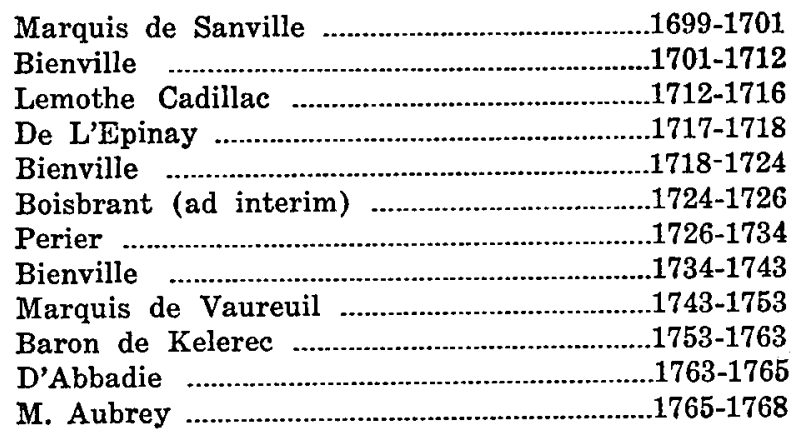

Spanish Provincial Governors

Antonio de Ulloa ............................................1767-1768

Alexander O'Reilly ..........................................1769-1770

Luis de Unzaga .................................................1770-1777

Bernardo de Galvez .........................................1777-1784

Esteven Miro ..................................................1784-1791

Francisco de Luis Hortu ................................1791-1797

Gayoso de Lemos ............................................1797-1799

Sebastian de Caso Calvo y O'Ferrell .............1799-1801

Juan Manuel de Salsedo .....................................1801-1803

Only one of the French rulers made a deep impress on history. It was during one of several administrations by Mr. Bienville that Iowa land was actually touched. The French rule spread out from Montreal to the west, which was reached through Detroit or Mackinaw. The fur buyers and missionaries led the van. The Indians were backing up. The Sac tribe had been encountered near Lake Champlain, but on the way west they had paused in what is now Wisconsin. A French officer had been killed, and an expedition was organized to punish the Sac tribe. The latter fled beyond the Mississippi and joined with their friends, the Fox tribe, and formed the coalition that lasted many years. The military expedition, under command of Captain Nichols Joseph de Noyelles, composed of French soldiers and Indian auxiliaries, entered Iowa at the north and followed the In- 
dian trail to the Raccoon forks of the Des Moines. There, in April 1735, a duel was fought. The result was not what the pursuers expected. The Sac and Fox warriors were not exterminated. The French commander returned home without any trophies. That battle was fought not far from where now stands the capitol of Iowa. But Bienville was a vigorous ruler and extended the French influence far down the valley.

\section{SPANISH RULERS SUPPLANT FRENCH}

Louisiana became a thoroughly French colony and in its commercial and social phases remained so all through the Spanish regime. When as a result of the FrenchIndian war, the British crown despoiled France of American possessions, Louisiana was tossed into the lap of the King of Spain. The change was not to the liking of the French colonists in Louisiana. The first of the Spanish governors, Antonio de Ulloa, seems to have been incompetent, as a result of which the French colonists started an insurrection. The colonists went so far as to expel Ulloa and prepared for some sort of independence. But the Spanish authority was restored by Alexander O'Reilly, an Irishman who dearly loved a fight. How Alec came to his high position in Spain is another story, but all accounts agree he was a ruthless and cruel ruler, who restored order by force and bloodshed. The French colonists outnumbered the Spanish and did not give up the hope that they might be again under French rule, or at least free from Spanish rule. The disturbed condition of political affairs in Europe encouraged them in this idea.

Already, before the American Revolution of 1776, the American influence was being felt in Louisiana, and in the struggle of the colonies along the coast to establish independence the Spanish power was thrown against Great Britain. Governor Bernardo Galvz gave aid to the American colonists and captured the British posts in West Florida. Of course the Spanish help for American colonists was not for love of the colonists, but for dislike of Britain. 
Another Irishman appears on the pages of history with a name somewhat Spanished. This is the Marquis Sebastian de Caso Calvo y O'Ferrell. He was allied by marriage to Governor O'Reilly and had been with the latter at New Orleans. He also saw something of the bloody revolution in San Domingo. He was in command of troops on that island when the revolting blacks cut the throats of several hundred French citizens. He was a native of Havana and was governor of Louisiana 17991801. He seems to have been less bloodthirsty than O'Reilly. He was designated later by the Spanish government to be one of the commissioners for the transfer to France. He remained in Louisiana so long afterwards that he fell under suspicion and was requested to leave the country.

\section{AMERICANS TAKE OVER}

Under the governors for the United States the seat of executive authority shifted, and included New Orleans, St. Louis, Vincennes, Detroit and Belmont. Gradually the military influence receded. During the period 1821-1834, when Iowa was a no-man's-land and not a part of any territory, the only government was military.

UNITED STATES GOVERNORS

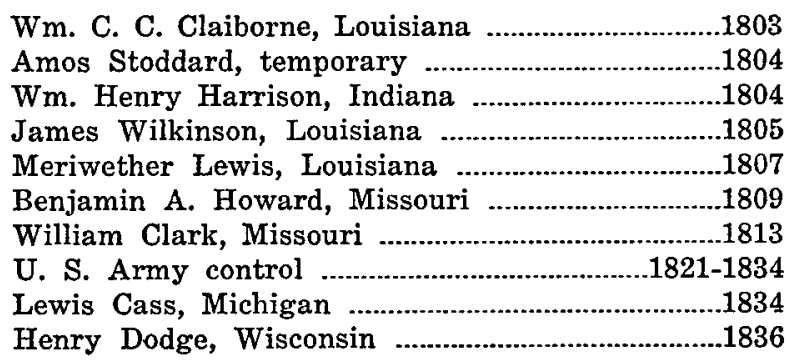

The prairies of Iowa were a long way from Washington, and still farther from Madrid and Paris at the time Napoleon sold Louisiana, which he didn't own, to representatives of Jefferson, who didn't want it, for a few dollars the seller much needed and the purchaser didn't have, the details of the transference being negotiated 
by Robert Livingston and James Monroe; hence the history of the transactions that followed immediately are not all clear in the history books.

At that precise time, the French government had sent Pierre de Laussat to New Orleans to assume French authority in the province, in accord with the treaty made in 1800. He at least nominally held control for 30 days prior to Dec. 20, 1803, when the province was turned over to Governor Claiborne and General Wilkinson. The former was governor of the Territory of Mississippi and the latter a notable officer in the U. S. army. As commissioners on behalf of the United States they assumed authority over all Louisiana, which extended to the far north. Claiborne resigned his Mississippi territory job and remained with Louisiana. He became governor to the territory of Orleans and first governor of the state of Louisiana. The last Spanish governor of Louisiana was Salsedo, but his predecessor joined with him in ceremonies of relinquishing Spanish rights.

The transfer at New Orleans, where the French flag flew only twenty days over the province, did not complete the transfer to the United States. There was a Spanish lieutenant governor at St. Louis with authority over Upper Louisiana or all above Memphis. This was Don Carlo de Lassus. Letters. were received by him early in 1804 notifying him it was time to haul down the Spanish flag. He got orders from Salsedo and Caso Calvo, and from Claiborne, telling him about the deal. He was also notified by De Laussat that Amos Stoddard had been designated to represent the French authority in the matter of the transfer. Accordingly, on March 9, 1804, Capt. Amos Stoddard arrived in St. Louis with a small detachment of troops from Kaskaskia. Meriwether Lewis was there. The exchange of letters all 'round indicated that the American flag would be quite welcome in St. Louis. An elaborate ceremony was arranged. Stoddard represented both the French and American governments. The Spanish flag was hauled 
down at the fort, and the French went up. A little later the French flag came down and the American stars and stripes appeared. There were about 300 people living in St. Louis at the time and they were all out to hurrah for the new flag. Captain Stoddard issued an order appointing all the Spanish military officers for similar civilian posts and directing that no changes be made for the time being. Thus it was that the region which is now Iowa became American in March 1804. It was several months later before all the Spanish soldiers went away.

\section{Louisiana District AtTached to Indiana Territory}

Gen. Wm. H. Harrison was governor of Indiana territory immediately adjacent to Upper Louisiana, and he was designated to exercise governorship over the newly acquired District of Louisiana, which was in fact Upper Louisiana. Harrison arrived in St. Louis Oct. 1, 1804, Capt. Stoddard having been in charge for six months. The seat of administration for the territory was therefore made at Vincennes, which was Harrison's official station. The laws of Indiana territory were applied to the District of Louisiana.

Largely through the efforts of Harrison, Upper Louisiana, which had all along been treated as separate from either Louisiana or the Isle of Orleans, became Louisiana Territory in 1805. Evidently Harrison was glad to be through with trying to be the boss, as he had abundance of trouble in the big region east of the river. The Indian wars were in sight and the Battle of Tippecanoe was yet to be fought. In the south the Territory of Orleans had been made out of the old Spanish province. Civil governments were coming to replace military; but the fact that nearly all the governors appointed from Washington were military men showed that the frontier problems were even then mostly for the army.

When the District of Louisiana was set going as the Louisiana Territory in 1805, President Jefferson sent to be first governor, Gen. James Wilkinson. The terri- 
tory became a reality March 3, 1804. General Wilkinson is a strange character in American history-eminent soldier of the Revolution, commander in chief of the U. S. army, commissioner to handle Louisiana affairs, organizer of a movement to separate Kentucky from the union, tried for connection with the Burr conspiracy, and known to have been in the pay of the King of Spain while still pretending to represent American interests, and so on. Despite positive proof of his disloyalty, or at Ieast duplicity and scheming, he retained the confidence of Jefferson. Of his administration little is known save that he got into much trouble and was disliked.

Lieut. Meriwether Lewis was also the special friend of Jefferson. He had been secretary to the president when he was sent with Gen. William Clark to make the journey up the Missouri river to the Pacific. He was appointed to succeed Wilkinson, and served well for a brief time.

Benjamin A. Howard, also a soldier and statesman, became governor. He had been a congressman in Kentucky and also long connected with the army. It was while he was governor of Louisiana territory that Orleans territory was admitted as a state with the name Louisiana. This suggested that a new name must be found for Louisiana territory, and it was renamed Missouri territory. So Mr. Howard was the last of the governors of Louisiana territory and first for Missouri territory. Then he was succeeded by Gen. William Clark, the associate of Lewis on the western expedition. Clark seems to have been governor of Missouri territory until the state of Missouri was organized in $\mathbf{1 8 2 1}$.

\section{IOWA SECTION UNORGANIZED}

Then followed the period when Iowa was without any headship-the thirteen years from 1821 to 1834 . Whatever government existed was military. It was during this period that the state makers at Washington planned to convert what is now Iowa into a perpetual Indian 
reservation. The frontiersmen ruled otherwise. The long rifle and the breaking plow vetoed everything that was intended to keep Iowa a wilderness.

Lewis Cass was governor of Michigan during the brief period when Iowa was a part of that territory ; and Henry Dodge was governor of Wisconsin while Iowa was part of that territory.

There were two rather peculiar phases of Iowa history as related to the rulers and the governors. One was that time just mentioned when the land was left virtually without any government for thirteen years, a time when the homeseekers were crossing the Mississippi in whole regiments and taking possession of the rich land. The other was that earlier time when from 1800 to 1803 , the Province of Louisiana was supposed to be a French possession, but Spanish officials remained in full control. It might easily have been that Iowa could have become either French or Spanish or part of an independent nation. The diplomatic and military moves were confusing and adventurers were scheming. Fortunately the good sense of American pioneers reached a wise solution to all problems.

\section{FUNDS FROM LAND FOUNDED ASYLUM}

Gov. Stephen Hempstead: By an act of the general assembly approved February 5, 1851, it was provided that as soon as the congress of the United States should give their consent, the saline lands belonging to the state might be sold, and the proceeds thereof constitute a fund for the founding and support of a lunatic asylum; and that five thousand dollars of the principal thus obtained, should be applied under the direction of the superintendent of public instruction, for the use of the College of Physicians and Surgeons at Keokuk.-Message to House of Representatives, Jan. 11, 1853. 
Copyright of Annals of Iowa is the property of State of Iowa, by \& through the State Historical Society of Iowa and its content may not be copied or emailed to multiple sites or posted to a listserv without the copyright holder's express written permission. However, users may print, download, or email articles for individual use. 